\title{
Identity of mass-flowering crops moderates functional trait composition of pollinator communities
}

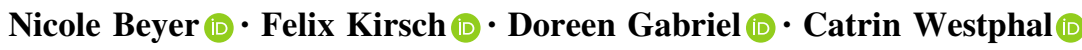

Received: 18 February 2021 / Accepted: 10 May 2021 / Published online: 22 May 2021

(C) The Author(s) 2021

\begin{abstract}
Context Pollinator declines and functional homogenization of farmland insect communities have been reported. Mass-flowering crops (MFC) can support pollinators by providing floral resources. Knowledge about how MFC with dissimilar flower morphology affect functional groups and functional trait compositions of wild bee communities is scarce.

Objective We investigated how two morphologically different MFC, land cover and local flower cover of semi-natural habitats ( $\mathrm{SNH})$ and landscape diversity affect wild bees and their functional traits (body size, tongue length, sociality, foraging preferences).
\end{abstract}

Nicole Beyer and Felix Kirsch contributed equally to this publication.

Supplementary Information The online version contains supplementary material available at https://doi.org/10.1007/ s10980-021-01261-3.

N. Beyer $(\bowtie) \cdot$ F. Kirsch · C. Westphal

Functional Agrobiodiversity, Department of Crop

Sciences, University of Göttingen, Göttingen, Germany

e-mail: nicole.beyer@uni-goettingen.de

D. Gabriel

Institute for Crop and Soil Science, Julius Kühn-Institut (JKI), Braunschweig, Germany

C. Westphal

Centre of Biodiversity and Sustainable Land Use (CBL), University of Göttingen, Göttingen, Germany
Methods We conducted landscape-level wild bee surveys in SNH of 30 paired study landscapes covering an oilseed rape (OSR) (Brassica napus L.) gradient. In 15 study landscapes faba beans (Vicia faba L.) were grown, paired with respective control landscapes without grain legumes.

Results Faba bean cultivation promoted bumblebees (Bombus spp. Latreille), whereas non-Bombus densities were only driven by the local flower cover of SNH. High landscape diversity enhanced wild bee species richness. Faba bean cultivation enhanced the proportions of social wild bees, bees foraging on Fabaceae and slightly of long-tongued bumblebees. Solitary bee proportions increased with high covers of OSR. High local SNH flower covers mitigated changes of mean bee sizes caused by faba bean cultivation.

Conclusions Our results show that MFC support specific functional bee groups adapted to their flower morphology and can alter pollinators ' functional trait composition. We conclude that management practices need to target the cultivation of functionally diverse crops, combined with high local flower covers of diverse $\mathrm{SNH}$ to create heterogeneous landscapes, which sustain diverse pollinator communities.

Keywords Wild bees $\cdot$ Ecosystem services $\cdot$ Floral resources · Legumes · Greening · Functional traits 


\section{Introduction}

Insects are declining worldwide (IPBES 2019) and the loss of insects acting as pollinators, such as wild bees, poses a threat to ecosystem services in natural and agricultural systems (Potts et al. 2010). In Germany alone, $53 \%$ of all native bee species are red listed (Westrich et al. 2011). Agricultural intensification through increased use of pesticides, the simplification of landscapes and the vanishing of nesting sites and food resources poses a big challenge to most pollinators (Potts et al. 2010; Vanbergen and Insect Pollinators Initiative 2013). The loss of suitable habitats can lead to a functional homogenization of insect communities through filtering for specific species traits but local effects can be mitigated by increasing landscape heterogeneity (Gámez-Virués et al. 2015; Perović et al. 2015).

The availability of floral resources is the main driver of wild bee abundances (Potts et al. 2003) and the loss of floral host species in the past century is a major reason for wild bee declines (Scheper et al. 2014). Heterogeneous landscapes with a high diversity of different habitats harbor diverse pollinator communities (Shackelford et al. 2013; Steckel et al. 2014) and increasing the amount of SNH in a landscape enhances wild bee abundance and species richness (e.g. SteffanDewenter et al. 2002; Nayak et al. 2015). In addition to the amount of SNH in a landscape, the quality of SNH, in terms of flower cover of important forage plants might be an essential factor shaping pollinator responses (Bartual et al. 2019) since both a high local flower cover and plant species richness are positively correlated with wild bee abundances and species richness (Potts et al. 2003; Kallioniemi et al. 2017).

Also, the cultivation of mass-flowering crops (MFC) can benefit wild bees by temporary providing high pollen and nectar amounts (Westphal et al. 2003; Diekötter et al. 2014; Rundlöf et al. 2014). The most commonly grown MFC in Europe is oilseed rape (OSR) (Brassica napus L.). But due to extreme drought during summer, cultivation area dropped by $28 \%$ from 2018 to 2019 , accounting for $7.4 \%$ of the total German cropland (Destatis 2020). Other MFC, like grain legumes, are rarely cultivated $(1.7 \%$ of cropland in Germany), although their cultivation area increased due to their promotion as ecological focus area (EFA) within the CAP greening reform of 2013 (Destatis 2020).
Successful crop pollination depends on the availability of suitable pollinators, whose morphological traits match those of the crops ' flowers (Garibaldi et al. 2015). Vice versa, flower visiting pollinator communities of different MFC vary (Garratt et al. 2014). While OSR is visited by a diverse pollinator community (Garratt et al. 2014), only a few pollinator species, mainly honeybees and bumblebees, forage on faba beans (Vicia faba L.) (Garratt et al. 2014; Marzinzig et al. 2018). This is due to the complex flower morphology of faba beans and nectar located deep in the corolla tubes (Bond and Poulsen 1983). Force and a long tongue are necessary to access the flowers" reward (Bailes et al. 2018). Long-tongued bumblebees are therefore most effective pollinators of faba beans (Marzinzig et al. 2018), while solitary wild bees have been shown to be most effective pollinators for oilseed rape (Woodcock et al. 2013).

Regarding biodiversity benefits of MFC, the identity of the flowering crop might determine, which pollinator species are promoted with possible implications for functional trait compositions of pollinator communities (Diekötter et al. 2010). Beneficial effects of early flowering OSR on bumblebees and solitary wild bees are widely known (e.g. Westphal et al. 2003, 2009; Jauker et al. 2012; Diekötter et al. 2014), whereas there are only few studies, showing a positive effect of faba bean cultivation on bumblebees (Knight et al. 2009; Hanley et al. 2011). There is limited understanding of how MFC with differing flower morphologies, interactively affect wild bee communities in SNH of agricultural landscapes. Especially possible landscape-scale effects on the functional trait composition of wild bee communities are understudied.

In this study, we aim to investigate how crop identity of two MFC species affects wild bee densities, species richness and their functional traits in $\mathrm{SNH}$ at landscape-scale. Moreover, we focus on the relative importance of local flower cover of $\mathrm{SNH}$, the amount of $\mathrm{SNH}$ and landscape diversity for wild bees. We established 30 paired $1 \mathrm{~km}^{2}$ study landscapes, i.e. 15 study landscapes with $V$. faba fields and 15 without grain legumes. We expect that faba bean cultivation increases mainly the number of bumblebees, the main pollinators of $V$. faba, by offering mid-seasonal resources. Further, we hypothesize that all wild bees benefit from an enhanced coverage of OSR, from an enhanced amount and local flower cover of SNH in the 
study landscapes and high landscape diversity. We expect local and landscape resource availability to modify the functional trait composition of wild bee communities, regarding bee size, foraging preferences, sociality and bumblebee tongue length. With respect to faba bean flower morphology, bigger pollinators, which are heavier and have proportional longer tongues and bees known to forage on Fabaceae should be favored by its cultivation. In contrast, OSR with nectar being easily accessible from flowers might promote predominantly small bees with proportional shorter tongues and bee species with no preference for Fabaceae. We expect social bees to be attracted by and to benefit from both MFC stronger than solitary bees. In addition, we hypothesize, that especially long tongued and big bumblebees, might be favored by faba bean cultivation because their morphology facilitates access to the reward of the flowers.

\section{Methods}

\section{Study design}

We selected 30 paired $1 \mathrm{~km} \times 1 \mathrm{~km}$ study landscapes in three different regions in Germany (see Beyer et al. 2020) (Fig. 1). Twelve landscapes were situated close to Göttingen in Central Germany $\left(51^{\circ} 32^{\prime} \mathrm{N}, 9^{\circ} 56^{\prime} \mathrm{E}\right)$, ten landscapes close to the North Sea in vicinity of the city Itzehoe $\left(53^{\circ} 55^{\prime} \mathrm{N}, 9^{\circ} 30^{\prime} \mathrm{E}\right)$ and eight in eastern Germany close to Leipzig $\left(51^{\circ} 20^{\prime} \mathrm{N}, 12^{\circ} 22^{\prime} \mathrm{E}\right) .15$ landscapes were surrounding a conventionally managed faba bean field (faba bean landscapes: FB +). We ensured that the respective farmers applied diversified crop rotations, i.e. conventional crop sequences that included grain legumes as an additional component for at least three years. Respecting control landscapes $(\mathrm{FB}-$ ) did not include any grain legumes. Landscape selection was based on a similar landscape composition of the study landscapes within a pair. For further details see Beyer et al. (2020).

All landscape elements with a minimum size of 10 $\mathrm{m}^{2}$ were mapped within the study landscapes by site inspections. As landscape composition measures, we calculated the percentage cover of semi-natural and flower-rich habitats (SNH, Table S1), landscape diversity (Shannon index of 14 land-use types; see appendix for further information) and percentage cover of mass-flowering OSR with QGIS version
2.18 (QGIS Development Team 2016). Our study landscapes covered an independent gradient of $\mathrm{SNH}$ and OSR (Fig. S1).

\section{Wild bee sampling}

The study was conducted during the summer of 2017 and wild bee sampling was repeated three times between May and August (early summer: 22.05.19.06., mid-summer: 22.06.-20.07., late summer: 27.07.-22.08.). Oilseed rape full bloom was over when sampling started. Faba beans were in full bloom during the first sampling run in early summer and did not flower during the last two sampling runs for most of the study landscapes. During every sampling run six variable transect walks $(50 \mathrm{~m} \times 5 \mathrm{~m}, 5 \mathrm{~min}$. excluding handling time) were conducted within the most attractive flower rich $\mathrm{SNH}$ in each study landscape to cover the entire spectrum of suitable foraging patches for wild bees at landscape scale (Westphal et al. 2008) (Fig. 1). Due to the high spatial and temporal floral variability in $\mathrm{SNH}$, we think that varying the transect location according to floral availability is a good approach to capture the entire pollinator community in each study landscape across the season. To cover different structural SNH types, we distributed the transect walks, if possible, equally within both, woody and grassy SNH types (for details see Table S1 and S2).

Transect walks were conducted between 9 a.m. and 7 p.m. on days with suitable weather conditions (no rain, low wind speed, temperatures $>15^{\circ} \mathrm{C}$ ). Walking slowly through the transect in one direction, the number of flower-visiting bees was counted. Species, that could not be identified in the field, were caught and taken to the lab for further identification. To avoid excessive killing, we collected only the first five bumblebee individuals of every species/morphospecies per transect for confirmatory identification. Based on similar coloration, we defined three morphospecies: (1) Bombus terrestris, B. lucorum, B. hortorum, B. bohemicus and B. sylvestris, (2) B. lapidarius, B. ruderarius and B. rupestris, (3) B. pascuorum and B. muscorum. All other bumblebee species could be distinguished as separate species. We identified all bumblebees (Mauss 1994) and all nonBombus wild bees (Amiet et al. 2001, 2007, 2014) in the lab. Because Bombus terrestris, B. lucorum, B. cryptarum and B. magnus are difficult to distinguish, 


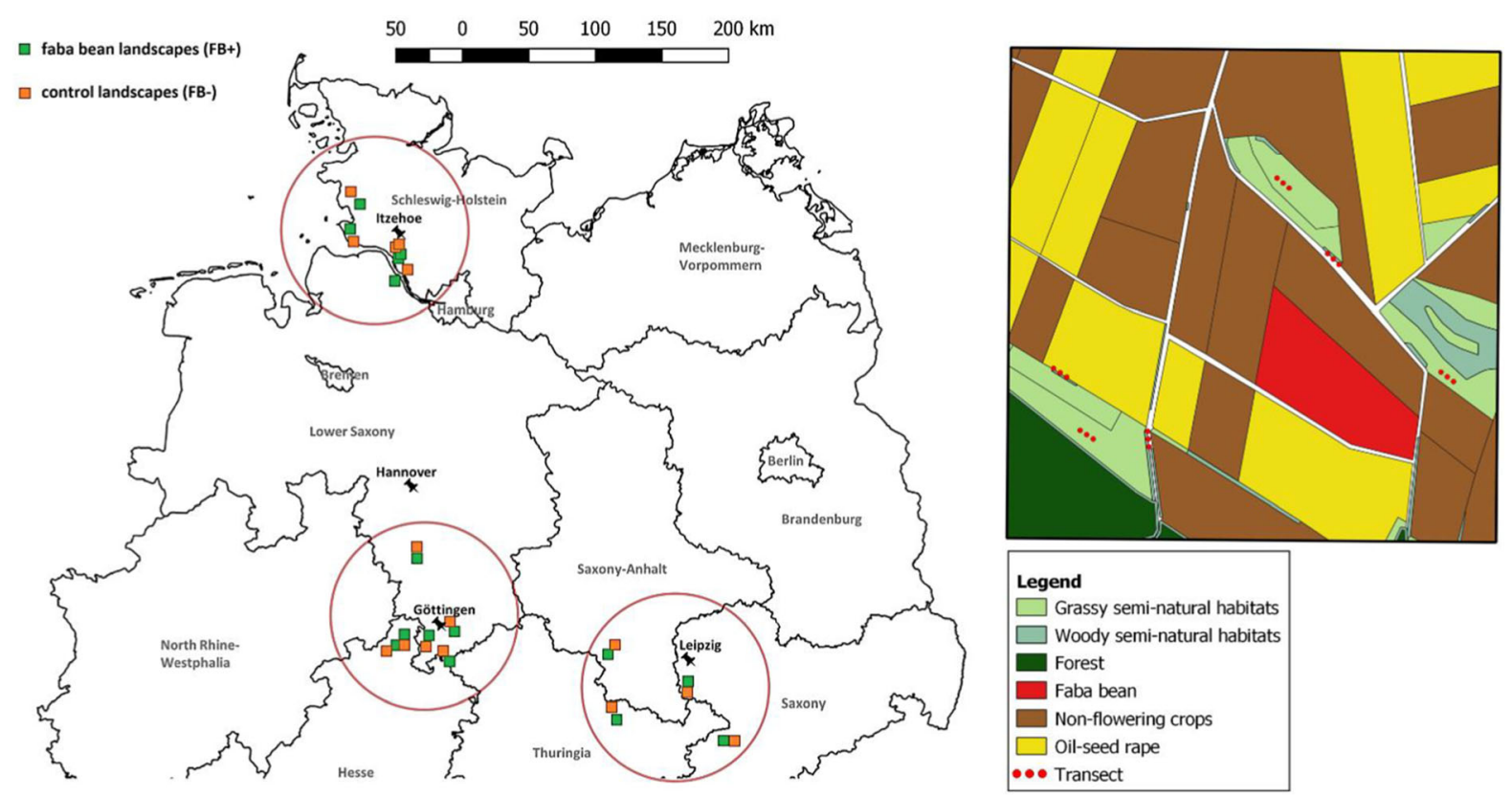

Fig. 1 Map showing the location of the study landscapes in the three regions of Germany. Landscapes with faba bean cultivation $(\mathrm{FB}+)$ are depicted in green and control landscapes $(\mathrm{FB}-)$

we aggregated them. The percentage of local flower cover within the transect area was estimated during each transect walk (mean: 28.7\%, range: 0-95\%). Flowering plants, on which we observed pollinator visits were recorded on family level (Fig. S2).

Functional trait composition of pollinator communities

To study the effects of faba bean cultivation and landscape metrics on the functional trait composition of wild bee communities, we chose three functional traits, likely to be affected by local and landscape resource availability: body size, foraging preferences and sociality. Trait analyses were conducted for all sampled wild bees. Since we collected only the first five individuals of every Bombus color group per transect, the sampled bumblebee individuals do not mirror the actual structure of the bumblebee community in a certain study landscape. To account for the community structure, we only considered the first five collected bumblebee individuals per transect for the trait analyses. We consider this sub-sample to be representative as the mean density of recorded bumblebees per transect was 3.8 and in approx. $80 \%$ of the in orange. On the right, an example of a study landscape is shown with six transects located in grassy and woody seminatural habitats

cases we only caught five or less bumblebee individuals per transect. We excluded cleptoparasites from the trait analyses (six species) because of their different life-history strategy and undefined foraging preferences. We measured the intertegular distance (ITD) of at least one and maximum five worker individuals per species (57 species in total) as a measure of body size (Table S3). For four species we caught only one single male individual and thus were not able to measure ITD. For the foraging preferences, wild bees were categorized into species collecting pollen from Fabaceae (any species, known to forage on Fabaceae, not specifically Fabaceae specialists) and species not known to exploit Fabaceae (specialists of a different plant family or generalists, not known to visit Fabaceae). For sociality, wild bees were grouped into social and solitary bees. Foraging preference and sociality information were extracted from the literature (Westrich 2018) (Table S3).

Since bumblebees are the main pollinators of faba beans, we additionally tested whether MFC affect the functional trait composition of bumblebee communities concerning bumblebee body size and tongue length. The tongue length of maximum 12 bumblebee workers per species was measured and the tongue 
length relative to the bees ' body sizes were calculated. According to the mean relative tongue length, bumblebee species were assigned to the long- or shorttongued category (Table S4).

\section{Statistical analyses}

All analyses were conducted in $\mathrm{R}$ version 3.6.1 ( $\mathrm{R}$ Core Team 2019) using generalized linear mixed models with the glmmTMB package (Brooks et al. 2017) and linear mixed effect models with the nlme package (Pinheiro et al. 2019). We followed a multimodel inference approach (Burnham and Anderson 2002). Based on global models (see details below), we fitted candidate models containing all possible combinations of explanatory variables and their interactions with the help of the dredge function of the MuMIn package (Barton 2019). The number of variables in the single candidate models was restricted to a maximum of seven. Candidate models were ranked by Bayesian Information Criterion (BIC), which is an information criterion similar to the more commonly used Akaike information criterion (AIC), but with a penalty term that also considers the number of samples. BIC thus tends to select less complex models in comparison to AIC (Burnham and Anderson 2002; Link and Barker 2006). We considered all models with a delta BIC $<2$ compared to the best fitting model to have important empirical support (Raftery 1995). We used BIC model weights $\left(w_{i}\right)$, to assess the posterior probability of each model (Link and Barker 2006) and derived the sum of BIC model weights $\left(\Sigma w_{i}\right)$ across all models to rank the importance of explanatory variables.

We used residual plots to validate model assumptions. As a measure of the model's goodness of fit we calculated marginal $\left(\mathrm{R}_{\mathrm{m}}{ }^{2}\right)$ and conditional $\left(\mathrm{R}_{\mathrm{c}}{ }^{2}\right) \mathrm{R}^{2}$ values with the MuMIn package. To test for collinearity, we used the variance inflation factor (VIF), which was below 3 for all cases (Zuur et al. 2010). To test for differences between faba bean and control landscapes or between different runs we performed post hoc tests with the emmeans package (Lenth 2019) at alpha level of 0.05. All graphics were generated with ggplot 2 package (Wickham 2016) and predictions and confidence intervals in scatter plots were obtained from the effects package (Fox and Weisberg 2019) and in the boxplots from the emmeans package.

\section{Wild bee densities and species richness}

To analyze the effect of local and landscape resource availability on pollinator densities, we performed two separate models for bumblebees and all other wild bees (non-Bombus wild bees). While all observed wild bees (excluding honeybees) were included in the wild bee densities, only identified individuals were used for the wild bee species richness. Overall species richness (see Fig. S3 for species accumulation curve) was analyzed at landscape scale (due to very low species numbers per transect), i.e. richness was calculated across all six transects per study landscape and run and SNH flower cover was averaged across all transects per study landscape and run. Our response variables were: density of bumblebees, density of non-Bombus wild bees (per $250 \mathrm{~m}^{2}$ transect area and $5 \mathrm{~min}$ ), species richness of all wild bees per study landscape (per 1500 $\mathrm{m}^{2}$ transect area and $30 \mathrm{~min}$ ), and additionally, density of the long-tongued B. pascuorum/ B. muscorum color group (hereinafter referred to as B. pascuorum densities, since B. muscorum made up only a small proportion of that group). We included faba bean cultivation $(\mathrm{FB}+/ \mathrm{FB}-$ ), local flower cover of the $\mathrm{SNH}$ transect area (FC), sampling run (early/mid/late summer), percentage of SNH and of OSR per study landscape and landscape diversity as explanatory variables in the global models. Moreover, we added all possible two-way interactions, as we consider each of them as ecologically relevant. All continuous explanatory variables were standardized to a mean of zero and a standard deviation of 1 to improve model convergence. As nested random effects, we included study region, landscape pair, study landscape and sampling run (region/landscape pair/landscape/run) into the pollinator density models and region, landscape pair and study landscape (region/landscape pair/landscape) into the species richness model.

Global generalized linear mixed models with all independent variables and two-way interactions were fitted with Poisson and in case of overdispersion with negative binomial distribution. For pollinator densities, models with and without zero inflation terms were compared and the model with lowest BIC was selected for multimodel inference. The zero inflation was either assumed to be constant across the data or to be related to the local flower cover (Brooks et al. 2017). The model with negative binomial distribution and without zero inflation term was selected for the bumblebee 
densities and for non-Bombus densities we chose the model with negative binomial distribution and zero inflation related to the local flower cover. For the species richness, we chose the model with Poisson distribution. To test for competition effects of honeybees on wild bee densities, we repeated density analyses as described above, with honeybee densities as additional predictor.

\section{Functional trait composition of wild bee communities}

To analyze the effects of faba bean cultivation and landscape metrics on the functional traits of wild bees at landscape level, we aggregated data across transects for each run. Using the $F D$ package (Laliberté and Legendre 2010), we calculated the community weighted means (CWM) for ITD for the entire pollinator community and for bumblebees seperately. We applied linear mixed effect models with Gamma distribution and log link for the entire wild bee community and with normal distribution for the analysis of CWM ITD of bumblebees. Moreover, we used generalized linear mixed models with binomial familiy and logit link to test the effect of local and landscape wide floral resources on the following response variables: the proportion of wild bees collecting pollen from Fabaceae (Fabaceae foragers) and the proportion of social wild bees relative to all bees as well as the proportion of long-tongued bumblebees relative to all bumblebees. The explanatory variables, random effects and multimodel inference procedure were the same as described above for the species richness.

\section{Results}

In total we observed 2620 wild bees of which $78.0 \%$ were bumblebees. 1342 wild bees were caught and used for species identification, resulting in 66 recorded species (Table S3). The most frequently caught wild bee was Bombus terrestris/lucorum accounting for about $29.7 \%$ of all sampled bees, making up $64.6 \%$ of all short-tongued bumblebees. B. pascuorum accounted for $24.4 \%$ of all wild bees and represented $82.8 \%$ of all long-tongued bumblebees. $12.2 \%$ of all collected bees were Bombus lapidarius. Lasioglossum pauxillum was the most commonly found non-Bombus bee and accounted for $5.2 \%$ of all wild bees. Most visited families of all visited plants in early summer were Fabaceae, Boranginaceae and Rosaceae, while in mid and late summer Fabaceae, Boranginaceae and Asteraceae were most visited (Fig. S2). $44.3 \%$ of all non-cuckoo species were categorized as Fabaceae foragers, which corresponded to $87.8 \%$ of all caught individuals.

Wild bee densities and species richness

The multimodel inference revealed two models within $\mathrm{dBIC}<2$ explaining the effect of faba bean cultivation $\left(\Sigma w_{i}=0.96\right)$, local flower cover $\left(\Sigma w_{i}=1.00\right)$ and run $\left(\Sigma w_{i}=1.00\right)$ on bumblebee densities (Tables 1 , $\mathrm{S} 5$, S6). We found on average 1.6 times more bumblebees in faba bean compared to control landscapes (Fig. 2a). The highest bumblebee densities were observed in run 2 and lowest in run 3 (Fig. S4). Moreover, bumblebee densities increased with increasing local flower cover and this effect was stronger in control compared to bean landscapes $\left(\Sigma w_{i}=0.66\right)$ (Fig. 2b).

There was a single model within $\mathrm{dBIC}<2$, showing positive effects of local $\mathrm{SNH}$ flower cover $\left(\Sigma w_{i}=1.00\right)$, on the density of non-Bombus wild bees (Tables 1, S5, S6, Fig. 2c). There were two best-fitting models, showing a positive effect of local SNH flower cover $\left(\Sigma w_{i}=1.00\right)$ and of landscape diversity $\left(\Sigma w_{i-}\right.$ $=0.67)$ on the species richness of all wild bees (Tables 1, S5, S6, Fig. 2d, e). Honeybees did not affect wild bee densities (see Tables S7 and S8).

Functional trait composition of wild bee communities

\section{All wild bees}

Functional composition of bee communities with respect to the bees' body sizes (CWM of ITD) were not affected by local or landscape resource availability. No fitted model was superior to the null model (Table 1).

Three models with dBIC $<2$ explained faba bean cultivation $\left(\sum w_{i}=0.99\right)$, run $\left(\sum w_{i}=1.00\right), \operatorname{OSR}\left(\sum w_{i-}\right.$ $=0.32)$ and SNH cover $\left(\Sigma w_{i}=0.40\right)$ effects on the proportion of social wild bees within the communities (Tables 1, S5, S6). We found a higher proportion of social bees in control compared to faba bean landscapes in run 1 , whereas a higher proportion of social 
Table 1 Summary of the best fitting candidate models $(\mathrm{dBIC}<2)$ and null models for the effects of faba bean cultivation and landscape metrics on bee densities, species richness and functional traits of all wild bees and bumblebees

\begin{tabular}{|c|c|c|c|c|c|c|c|c|}
\hline Response variable & Model & df & $\mathrm{BIC}$ & DeltaBIC & $\begin{array}{l}\text { BIC } \\
\text { weight }\end{array}$ & Explanatory variables & $\mathrm{R}_{\mathrm{m}}^{2}$ & $\overline{\mathrm{R}_{\mathrm{c}}{ }^{2}}$ \\
\hline \multicolumn{9}{|c|}{ Pollinator densities and species richness } \\
\hline \multirow{3}{*}{$\begin{array}{l}\text { Bumblebee density } \\
\qquad(n=540)\end{array}$} & m.bb1 & 11 & 2287.43 & 0.00 & 0.49 & $\mathrm{FB}+\mathrm{FC}+$ run $+\mathrm{FB}: \mathrm{FC}$ & 0.53 & - \\
\hline & m.bb2 & 10 & 2289.01 & 1.58 & 0.22 & $\mathrm{FB}+\mathrm{FC}+$ run & 0.52 & - \\
\hline & m.bb0 & 7 & - & - & - & 1 & - & - \\
\hline \multirow{2}{*}{$\begin{array}{l}\text { Non-Bombus density } \\
\quad(n=540)\end{array}$} & m.nb1 & 9 & 1268.77 & 0.00 & 0.59 & $\mathrm{FC}$ & 0.06 & 0.42 \\
\hline & m.nb0 & 7 & 1341.80 & 73.03 & 0.00 & 1 & 0 & 0.46 \\
\hline \multirow{3}{*}{$\begin{array}{l}\text { Species richness of all wild } \\
\text { bees }(n=90)\end{array}$} & m.spr1 & 6 & 408.82 & 0.00 & 0.26 & $\mathrm{FC}+\mathrm{LD}$ & 0.20 & 0.37 \\
\hline & m.spr2 & 5 & 409.69 & 0.88 & 0.17 & $\mathrm{FC}$ & 0.19 & 0.38 \\
\hline & m.spr0 & 4 & 421.61 & 12.79 & 0.00 & 1 & 0.00 & 0.33 \\
\hline \multicolumn{9}{|c|}{ Functional traits of all wild bees } \\
\hline CWM ITD $(n=90)$ & m.itd1 & 5 & 174.46 & 0.00 & 0.32 & 1 & 0.00 & 0.43 \\
\hline \multirow{2}{*}{$\begin{array}{l}\text { Foraging preferences } \\
\quad(n=90)\end{array}$} & $\mathrm{m} .11$ & 9 & 312.62 & 0.00 & 0.30 & $\mathrm{FB}+$ run + FB:run & 0.08 & 0.22 \\
\hline & m.10 & 4 & 333.93 & 21.30 & 0.00 & 1 & 0.00 & 0.14 \\
\hline \multirow[t]{4}{*}{ Sociality $(n=90)$} & m.s1 & 9 & 326.64 & 0.00 & 0.16 & $\mathrm{FB}+$ run + FB:run & 0.16 & 0.31 \\
\hline & $\mathrm{m} . \mathrm{s} 2$ & 10 & 327.76 & 1.12 & 0.09 & $\mathrm{FB}+$ run $+\mathrm{OSR}+\mathrm{FB}:$ run & 0.17 & 0.30 \\
\hline & m.s3 & 12 & 328.25 & 1.61 & 0.07 & $\mathrm{FB}+$ run $+\mathrm{SNH}+\mathrm{FB}:$ run + run:SNH & 0.18 & 0.33 \\
\hline & $\mathrm{m} . \mathrm{s} 0$ & 4 & 413.84 & 87.21 & 0.00 & 1 & 0.00 & 0.14 \\
\hline \multicolumn{9}{|l|}{ Functional traits of Bombus } \\
\hline \multirow{3}{*}{$\begin{array}{l}\text { Proportion long-tongued } \\
\text { bumblebees }(n=90)\end{array}$} & m.ltb1 & 7 & 361.28 & 0.00 & 0.33 & $\mathrm{FC}+$ run & 0.19 & 0.27 \\
\hline & m.ltb2 & 8 & 362.99 & 1.71 & 0.14 & $\mathrm{FC}+\mathrm{FB}+$ run & 0.20 & 0.27 \\
\hline & m.ltb0 & 4 & 431.28 & 70.00 & 0.00 & 1 & 0.00 & 0.18 \\
\hline \multirow{2}{*}{$\begin{array}{l}\text { CWM ITD Bombus } \\
\quad(n=90)\end{array}$} & m.itdb1 & 8 & -223.76 & 0.00 & 0.44 & $\mathrm{FB}+\mathrm{FC}+\mathrm{FB}: \mathrm{FC}$ & 0.18 & 0.18 \\
\hline & m.itdb0 & 5 & -219.62 & 4.15 & 0.06 & 1 & 0.00 & 0.00 \\
\hline
\end{tabular}

Marginal $\left(\mathrm{R}_{\mathrm{m}}{ }^{2}\right)$ and conditional $\left(\mathrm{R}_{\mathrm{c}}{ }^{2}\right) \mathrm{R}^{2}$ values are given as a measure of the model's goodness of fit. Data for species richness and for functional traits is summed up across all transects per study landscape. $n$ number of observations, $F B$ faba bean cultivation $(\mathrm{FB}+/ \mathrm{FB}-)$, run sampling run (early/mid/late summer), $F C$ local flower cover, $L D$ landscape diversity, $O S R$ percentage of oilseed rape, $S N H$ percentage of semi-natural habitats

bees was recorded in bean landscapes in comparison with controls in the second and third run (Fig. 3a). The proportion of social bees decreased with increasing amounts of OSR in the surrounding study landscape (Fig. 3b). We found proportions of social bees to increase with increasing percentage of $\mathrm{SNH}$ in run 1 and to decrease in run 2 and 3 (Fig. S5).

The multimodel inference resulted in one best model explaining faba bean cultivation $\left(\Sigma w_{i}=0.83\right)$ and run $\left(\Sigma w_{i}=1.00\right)$ effects on the proportion of Fabaceae foragers (Tables 1, S5, S6). Patterns were similar as for the proportion of social bees, which might be due to the correlation of the two response variables (spearman $r=0.74, p<0.001$ ). Proportions of Fabaceae foragers were higher in faba bean landscapes compared to controls in run 2 and 3 , whereas the opposite was true for run 1 (Fig. S6). Besides, composition of the bee communities was unaffected by faba bean cultivation but changed by OSR cover, mainly due to common bumblebee species (for further details see supplementary material Table S9 and Fig. S7).

\section{Bumblebees}

There were two models within $\mathrm{dBIC}<2$ explaining the effect of faba bean cultivation $\left(\Sigma w_{i}=0.40\right)$, sampling run $\left(\Sigma w_{i}=1.00\right)$ and local flower cover $\left(\Sigma w_{i}=1.00\right)$ on the proportion of long-tongued bumblebees (Tables 1, S5, S6). We found $51 \%$ of the 

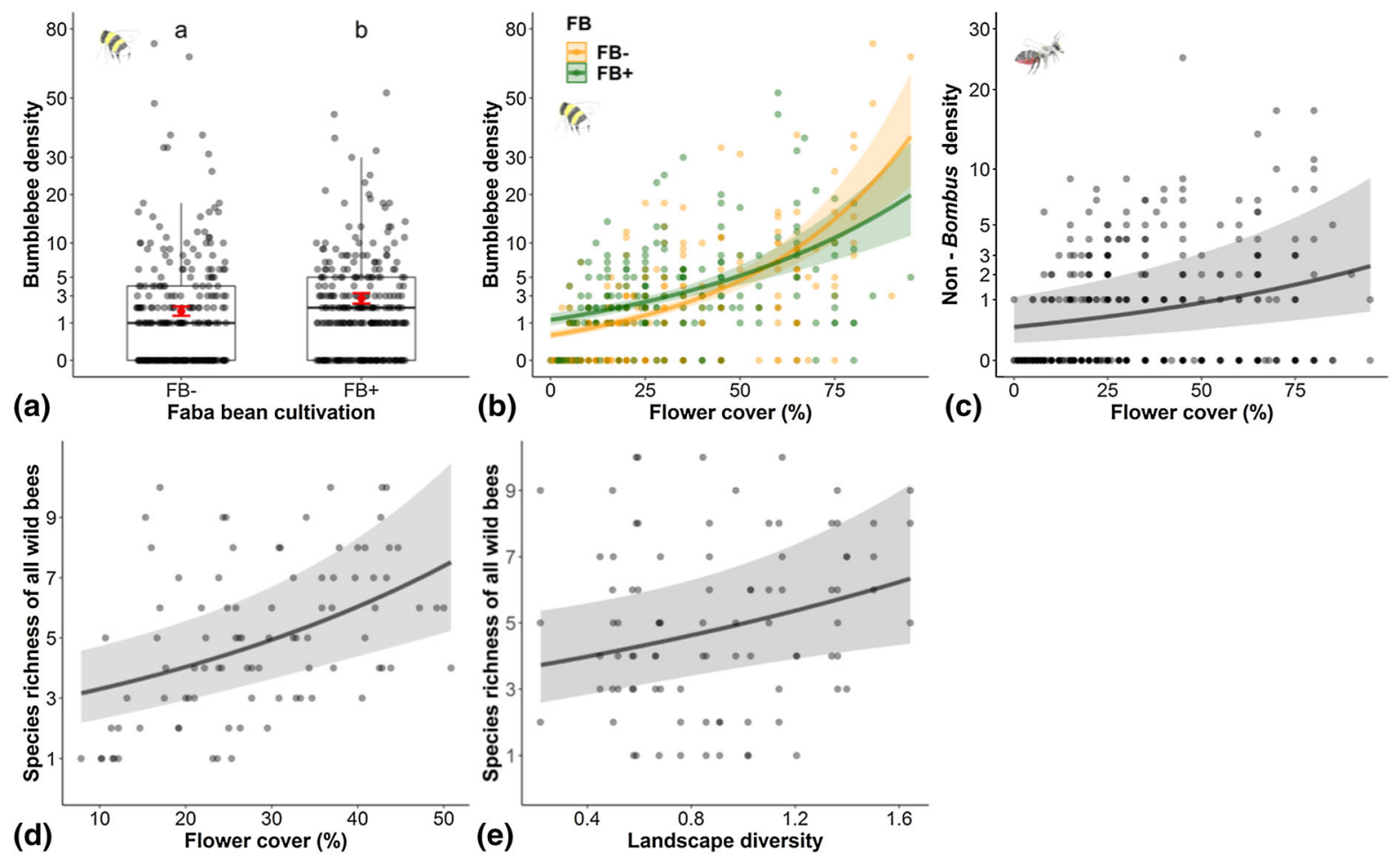

Fig. 2 Effect of faba bean cultivation on bumblebee densities in landscapes with $(\mathrm{FB}+)$ and without $(\mathrm{FB}-)$ faba bean cultivation $(p<0.001)$ (a). Effect of local flower cover $(\%)$ on bumblebee densities in FB + and FB- landscapes (b). Effect of local flower cover (\%) on non-Bombus wild bee densities (c) and on species richness of all wild bees (d). Effect of landscape diversity on wild bee species richness (e). Predicted mean values

bumblebee community to be long-tongued in faba bean landscapes and $42 \%$ in control landscapes ( $p=0.07$ ) (Fig. 4a). Highest proportions of longtongued bumblebees were present in the last sampling run (Fig. S8) and the proportions decreased with increasing local flower cover (Fig. 4b). Focusing on the most dominant long-tongued species, we found higher B. pascuorum densities in faba bean compared to control landscapes $(p<0.01)$ (Fig. S9). Densities were highest in run 2 and lowest in 1.

The CWM for ITD of bumblebees was fitted by a single best model including faba bean cultivation $\left(\Sigma w_{i}=0.90\right)$, local flower cover $\left(\Sigma w_{i}=0.88\right)$ and their interaction $\left(\Sigma w_{i}=0.86\right)$ as predictors (Tables 1 , S5, S6). Mean size of bumblebees did not differ between faba bean and control landscapes (Fig. 4c). CWM ITD increased with increasing flower cover in control landscapes, whereas it decreased in faba bean landscapes (Fig. 4d). CWM ITD was higher in faba and $95 \%$ confidence intervals are displayed (in red for (a)). Different letters above boxplots indicate significant differences between $\mathrm{FB}+$ and FB - landscapes. Predictions are based on the respective best fitting models m.bb1, m.nb1 and m.spr1 (Table 1). Y-axes are sqrt-transformed in $(\mathbf{a}-\mathbf{c})$ for graphical reasons

bean compared to control landscapes when local flower cover of SNH was low ( $p<0.01$ ), while at high local flower cover of SNH CWM ITD did not differ significantly $(p=0.07)$.

\section{Discussion}

Wild bee densities and species richness

We showed that faba bean cultivation enhances bumblebee densities in SNH, which is in accordance with our hypothesis. Accordingly, bumblebee densities were enhanced in faba bean landscapes, when sampling within field margins (Beyer et al. 2020). Bumblebees are known to preferentially forage on flowers, that offer high quality, protein-rich pollen, like Fabaceae (Somme et al. 2015) and are, next to honeybees, the most common flower visitors to faba 


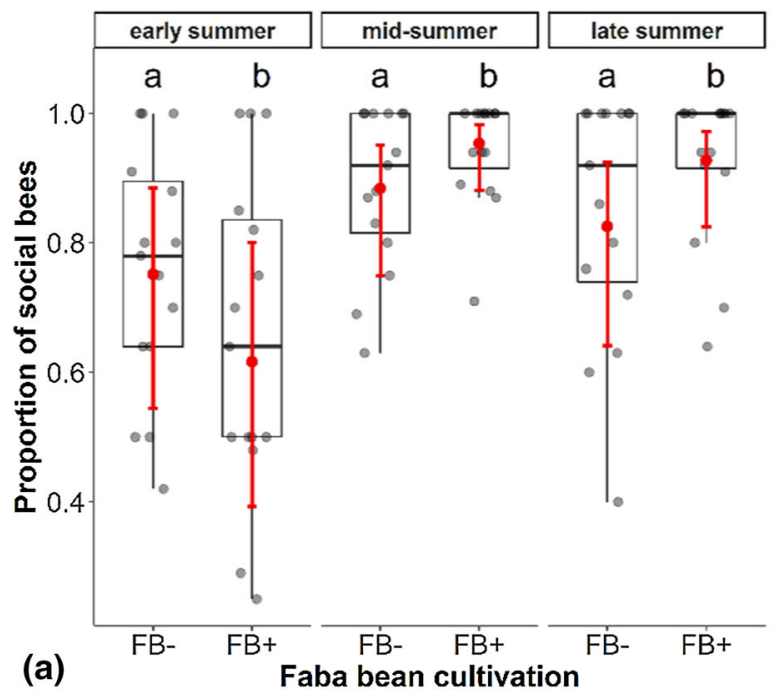

Fig. 3 Effect of (a) faba bean cultivation and of (b) oilseed rape cover on the proportion of social bees (for the three different sampling runs in (a)). Different letters above boxplots indicate significant differences between faba bean $(\mathrm{FB}+)$ and control

beans in temperate regions (Bond and Poulsen 1983; Garratt et al. 2014; Marzinzig et al. 2018). Due to their tongue length and body size, bumblebees“ morphology fits the morphology of faba beans with its very long corolla-tubes. Force and a long tongue is necessary to easily access nectar of faba bean flowers (Bailes et al. 2018). An increased colony density of long-tongued Bombus pascuorum in the vicinity of faba bean fields (Knight et al. 2009) and a higher density of bumblebees in field margins adjacent to bean compared to wheat fields (Hanley et al. 2011) has already been shown. However, the effect of faba bean cultivation on biodiversity at landscape-scale is widely unknown. Our study provides evidence that conventionally managed faba beans increase bumblebee densities at landscape-scale by providing resources during mid-summer after the flowering of OSR. Resource continuity is of major importance for pollinators to persist in simplified agricultural landscapes (Westphal et al. 2009; Schellhorn et al. 2015) and March, June and August/September have been identified as critical times of nectar scarcity for bumblebees (Timberlake et al. 2019). Thus, faba beans might provide essential resources for wild bees in times of food scarcity during June. Resource continuity throughout the season might be especially important for colonial species, while most solitary bees have shorter life cycles and depend on resource

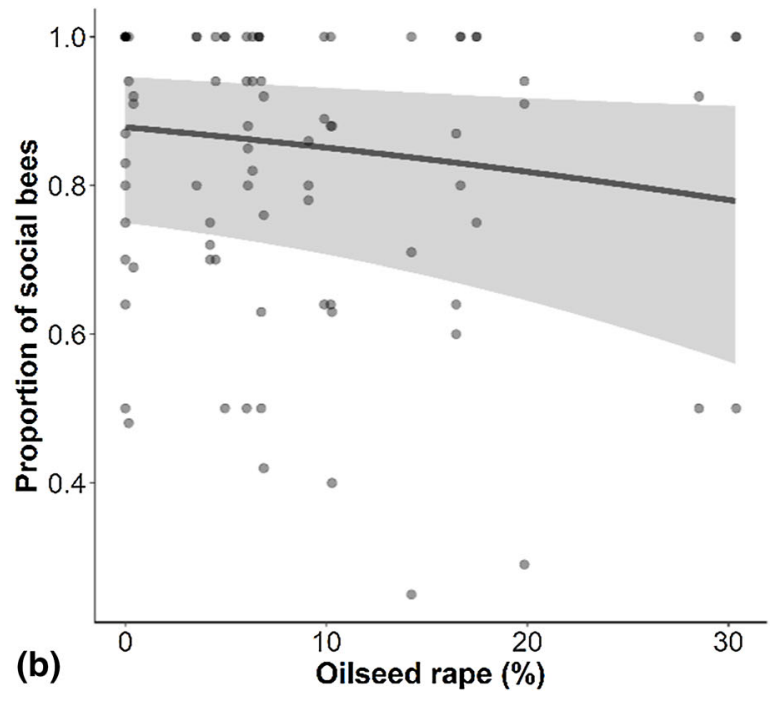

(FB-) landscapes within each run. Predicted mean values and 95\% confidence intervals are displayed (in red for (a)). Predictions are based on the second-best fitting model m.s2 (Table 1)

availability at the time of their activity period. This might be one reason for why non-Bombus wild bees did not benefit from faba bean cultivation. Another reason is the beans" flower morphology with rewards not easily accessible for small bees with short tongues. Non-Bombus wild bees and bumblebees were closely linked to the quantity of floral resources within the SNH of our study landscapes. Bumblebee densities increased more strongly with increasing local flower cover in control compared to bean landscapes. Faba bean cultivation might have mitigated the concentration of bumblebees on highly attractive SNH through the provisioning of an alternative resource. In addition to common grassland species, woody plant species were frequently used by our wild bees (Rosaceae in run 1), emphasizing their importance as wild bee forage plants (Kämper et al. 2016; Leidenfrost et al. 2020). While SNH flower cover was the most important determinant for non-Bombus wild bee densities recorded in the respective $\mathrm{SNH}$, the cover of SNH had no effect on wild bees. However, when investigating wild bees outside $\mathrm{SNH}$, such as field margins or crop fields, SNH cover has been shown to be an important driver of wild bee densities (Nayak et al. 2015; Beyer et al. 2020). Wild bees have been shown to shift between different crop and non-crop habitats in agricultural landscapes according to their flowering phenology and changing resource availability 

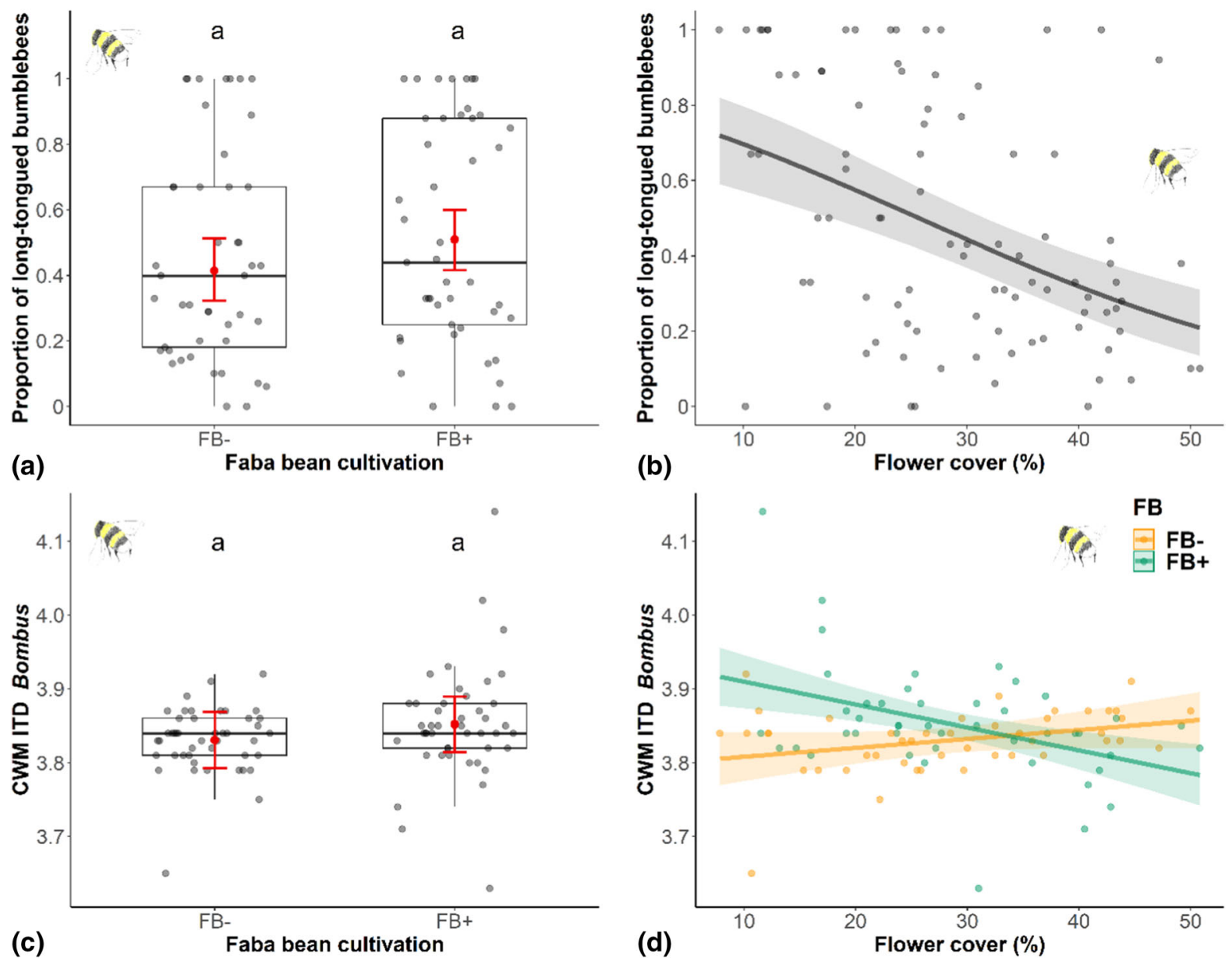

Fig. 4 Effect of faba bean cultivation $(p=0.07)(\mathbf{a})$ and of local flower cover $(\%)$ (b) on the proportions of long-tongued bumblebees. Effect of faba bean cultivation $(p=0.12)(\mathbf{c})$ and of local flower cover $(\%)(\mathbf{d})$ for faba bean $(\mathrm{FB}+)$ and control (FB-) landscapes on the community weighted means (CWM) for intertegular distance (ITD) of bumblebees. Same letters

(Mandelik et al. 2012). Similarly, local floral resource availability drove wild bees in our study. However, only bumblebees but not non-Bombus wild bees were additionally affected by landscape metrics, which might be explained by the larger foraging ranges of bumblebees compared to smaller and less mobile solitary bees (Greenleaf et al. 2007).

In addition to the local flower cover within $\mathrm{SNH}$, landscape diversity enhanced wild bee species richness. More complex landscapes might offer more diverse nesting and foraging habitats supporting diverse pollinator communities with different resource requirements (Shackelford et al. 2013; Perović et al. 2015). Our study provides important evidence that

above boxplots indicate non-significant differences between $\mathrm{FB}+$ and $\mathrm{FB}-$ landscapes. Predicted mean values and $95 \%$ confidence intervals are displayed (in red for (a and c)). Predictions are based on the second-best model m.ltb2 for the proportion of long-tongued bumblebees and on the best fitting model m.itdb1 for CWM ITD of Bombus (Table 1)

diverse and flower-rich landscapes are prerequisites to promote and conserve species-rich pollinator communities in often species-poor agricultural landscapes.

Contrary to our expectations, the cover of OSR did neither affect bumblebee, non-Bombus wild bee densities, nor wild bee species richness. OSR has been shown to be beneficial for wild bees (Westphal et al. 2003; Diekötter et al. 2014). Nevertheless, Westphal et al. (2009) showed that early positive effects on bumblebee colonies do not translate into a higher colony reproductive success later in the season. Similarly, the early resources provided by OSR in our study did not affect wild bees in SNH. Our sampling started after most OSR fields had ceased blooming in 
mid-May. Thus, a possible boost through an early resource pulse in April did not translate into persistent effects in our wild bee communities.

Functional trait composition of wild bee communities

\section{All wild bees}

Faba bean cultivation affected the proportion of social bees and of faba bean foragers in $\mathrm{SNH}$, depending on the sampling time. While we observed higher proportions in control than in bean landscapes when faba beans were in full bloom, the effect was reversed afterwards as also shown in Beyer et al. (2020). While a higher proportion of social bees might result from an increase of social bees or a decrease of solitary bees or both, those effects were probably driven by bumblebees, the most dominant group of social bees in our study landscapes. They are known to frequently forage on Fabaceae (Somme et al. 2015) and are attracted by mass-flowers (Walther-Hellwig and Frankl 2000). Most of them were likely to forage in faba bean fields instead of SNH, where we sampled, when beans were blooming. Such dilution effects driven by MFC have been already shown for OSR and might lead to diminishing pollination services for less attractive wild plant populations (Holzschuh et al. 2016). Similar effects are conceivable concerning faba bean flowering, pulling social bees away from SNH during their blooming period with possible negative implications for wild Fabaceae populations that are adapted and dependent on bumblebee pollinators. After the flowering of $V$. faba, we observed a higher proportion of social bees and Fabaceae foragers in bean than in control landscapes. This indicates that faba bean cultivation generally promotes social bees and bees foraging on Fabaceae. Again, this effect might be driven by the bumblebees through an enhanced colony growth facilitated by the additional resources provided by beans in June, as already shown for later flowering crops (Rundlöf et al. 2014).

High amounts of OSR in the surrounding landscape had a slightly negative effect on the proportion of social bees in wild bee communities found in $\mathrm{SNH}$. OSR is visited by a variety of different pollinator groups, with solitary wild bees as most effective pollinators (Woodcock et al. 2013). Solitary bees, which are known to be promoted by OSR (Diekötter et al. 2014; Jauker et al. 2012) might have benefited more than social bees, like bumblebees, which are associated with Fabaceae (Goulson et al. 2005). Our results indicate that high covers of OSR can modify the functional trait composition of wild bee communities in terms of sociality with resulting effects on the community composition.

In contrast to faba beans that enhanced the proportion of social bees and Fabaceae foragers, oilseed rape promoted solitary wild bees. Consequently, a single species of MFC cannot conserve functionally diverse wild bee communities in agricultural landscapes. Biodiversity conservation measures should therefore aim at increasing crop diversity, which is already one of the three CAP greening practices, farmers receive payments for. The introduction of the crop diversification measure in fact might have led to a decreased cultivation of common cereals in favor of an increased cultivation area of rape, sunflower and leguminous crops in 2015 (European Commission 2017). Nevertheless, agricultural management should also target the cultivation of morphologically different MFC to increase functional farmland plant diversity, which enhances pollinator diversity (Sutter et al. 2017).

\section{Bumblebees}

In addition to higher bumblebee densities, there was a slight tendency of enhanced proportions of longtongued bumblebees in faba bean compared to control landscapes. Additionally, we found enhanced densities of B. pascuorum in bean landscapes, which was the most dominant species of the long-tongued bumblebees (more than $80 \%$ ) in our study sites. Thus, faba bean cultivation promotes particularly longtongued bumblebee species. Long-tongued bumblebees have been shown to be most effective faba bean pollinators, while short-tongued species often rob nectar by biting holes into the corolla base (Bond and Poulsen 1983; Marzinzig et al. 2018). Many longtongued bumblebee species are threatened and the decrease of bumblebee forage plants, especially legumes, during the last decades has been postulated as a reason for their decline (Goulson et al. 2005). Most long-tongued bumblebee species emerge late (May/June) in contrast to the early emerging shorttongued bumblebees (Goulson et al. 2005). Likewise, we found highest proportions of long-tongued bumblebees in the latest run from mid-July to mid-August. 
Dietary specialization, a long tongue and a late emergence time have been related to rarity in bumblebees (Goulson et al. 2005). Hence, the cultivation of faba beans could help to promote rare longtongued bumblebee species, for which the faba bean provides valuable resources for colony establishment.

An increasing local flower cover led to higher proportions of short-tongued bumblebees. Shorttongued bumblebee species are known to be particularly attracted by mass-flowers (Walther-Hellwig and Frankl 2000) which explains their dominance in bumblebee communities when flower cover of SNH was high. The cover of OSR did not affect the functional composition of the bumblebee communities. Contrary, Diekötter et al. (2010) found decreased densities of long-tongued bumblebees with increasing amounts of OSR in the landscape. This pattern probably arose from competition effects through short-tongued bumblebees, which strongly profited from OSR, leading to higher rates of nectar robbing on red clover (Diekötter et al. 2010).

We found bumblebees to have higher mean sizes in faba bean compared to control landscapes when local flower cover of SNH was low. Faba beans provided additional resources in simplified agricultural landscapes, from which bumblebee colonies were likely to benefit (Knight et al. 2009). Bumblebees in complex landscapes with more floral resources have been shown to be larger than in simple landscapes (Persson and Smith 2011) since fewer resources result in smaller offspring (Oliveira et al. 2016; Radmacher and Strohm 2010). Another explanation might be that bigger bumblebees have proportional longer tongues and can apply more force, which is required to access the V. faba flower rewards (Bailes et al. 2018). The improved resource exploitation of big bumblebees is likely to have driven their dominance of the community. However, when local flower cover of SNH increased, the difference between bean and control landscapes regarding mean bee size disappeared. If bumblebees were resource limited in our study landscapes, more flower-rich $\mathrm{SNH}$ were likely to enable a bigger worker size through increased nectar and pollen supply, explaining increasing ITD of bumblebees in control landscapes. Accordingly, Grab et al. (2019) showed that the provisioning of floral resources can buffer against a decrease of bee body sizes due to the simplification of landscapes. Contrary, mean bumblebee size in faba bean landscapes decreased with increasing $\mathrm{SNH}$ flower cover. Increased alternative resource availability probably compensated for the dominance of big bumblebees, benefiting from faba beans and exerting competitive pressure on smaller bees. Potential wild bee functional trait composition changes driven by faba beans are therefore likely to be mitigated by a high floral resource supply of $\mathrm{SNH}$, i.e. heterogenous, resourcerich landscapes.

\section{Conclusions}

Our study shows that the identity of MFC moderates functional trait compositions of pollinator communities. Different MFC promote different functional groups of wild bees and the dominance of one MFC cannot conserve diverse pollinator communities. High OSR covers shifted bee communities towards a higher proportion of solitary wild bees. Faba bean cultivation enhanced bumblebee densities at landscape-scale and filtered for functional traits associated with Fabaceae. Social wild bees, bees foraging on Fabaceae and longtongued bumblebee species were promoted. Increased floral resource availability can buffer against changes of the functional trait composition regarding bumblebee size, caused by a dominance of faba beans in resource-poor landscapes. It is already known that the loss of suitable foraging and nesting habitats in simplified agricultural landscapes results in a functional homogenization of insect communities (GámezVirués et al. 2015; Perović et al. 2015). Since crop yields are positively correlated with functional pollinator diversity (Garibaldi et al 2015; Woodcock et al. 2019), it is desirable to conserve diverse pollinator communities, which requires a high landscape heterogeneity (Steckel et al. 2014; Perović et al. 2015) and a high functional diversity of farmland plants (Sutter et al. 2017). Farmland floral resources can be provided by either promoting SNH or by the cultivation of MFC and both approaches have already been shown to benefit pollinators (e.g. Westphal et al. 2003; Diekötter et al. 2014). Biodiversity conservation measures should therefore include both, off-field practices targeting SNH as well as on-field practices aiming at crop diversification, especially with respect to flowering crops with various flower morphologies. A high crop and landscape diversity, combined with a high quantity and quality of SNH can help to promote 
common crop pollinators, to conserve functional diverse pollinator communities and to ultimately secure crop yields.

Acknowledgements We thank all farmers and landowners, who allowed us to conduct our research on their land. We are grateful to Jens Dauber, Georg Everwand and Katharina SchulzKesting for their support during the study site selection and landscape mapping process. We thank Stefan Mecke for his supervision of the GIS based landscape analyses and selection of the landscape pairs. Dr. Hella Ludwig and Mike Kuschereitz supported the species identification, especially of the nonBombus wild bees, and we are grateful for their expertise and help. The study was conducted within the framework of the RELEVANT project. It is supported by funds of the Federal Ministry of Food and Agriculture (BMEL) based on a decision of the parliament of the Federal Republic of Germany via the Federal Office for Agriculture and Food (BLE) under the Federal Programme for Ecological Farming and Other Forms of Sustainable Agriculture (Project number 281 5EPSO 16). CW is grateful for being funded by the Deutsche Forschungsgemeinschaft (DFG) (Project number 405945293).

Author contributions CW conceived the study and supervised the project; NB and FK implemented the study sites; FK collected the data; NB performed data analyses with support of FK and advice of DG and CW; NB wrote the first manuscript draft. All authors contributed critically and gave final approval for publication.

Funding Open Access funding enabled and organized by Projekt DEAL.

Open Access This article is licensed under a Creative Commons Attribution 4.0 International License, which permits use, sharing, adaptation, distribution and reproduction in any medium or format, as long as you give appropriate credit to the original author(s) and the source, provide a link to the Creative Commons licence, and indicate if changes were made. The images or other third party material in this article are included in the article's Creative Commons licence, unless indicated otherwise in a credit line to the material. If material is not included in the article's Creative Commons licence and your intended use is not permitted by statutory regulation or exceeds the permitted use, you will need to obtain permission directly from the copyright holder. To view a copy of this licence, visit http://creativecommons.org/licenses/by/4.0/.

\section{References}

Amiet F, Herrmann M, Müller A, Neumeyer R (2007) Apidae 5. Ammobates, Ammobatoides, Anthophora, Biastes, Ceratina, Dasypoda, Epeoloides, Epeolus, Eucera, Macropis, Melecta, Melitta, Nomada, Pasites, Tetralonia, Thyreus, Xylocopa. Fauna Helvetica 20. CSCF and SEG, Neuchâtel.
Amiet F, Müller A, Neumeyer R (2014) Apidae 2. Colletes, Dufourea, Hylaeus, Nomia, Nomioides, Rhophitoides, Rophites, Sphecodes, Systropha. Fauna Helvetica 4. CSCF and SEG, Neuchâtel.

Amiet F, Müller A, Neumeyer R (2001) Apidae 3. Halictus, Lasioglossum. Fauna Helvetica 6. CSCF and SEG, Neuchâtel.

Bailes EJ, Pattrick JG, Glover BJ (2018) An analysis of the energetic reward offered by field bean (Vicia faba) flowers: Nectar, pollen, and operative force. Ecol Evol 8:3161-3171. https://doi.org/10.1002/ece3.3851

Barton K (2019) MuMIn: multi-model inference. R Package Version 1(43):6

Bartual AM, Sutter L, Bocci G, Moonen AC, Cresswell ME, Giffard B, Jacot K, Jeanneret P, Holland J, Pfister S, Pintér O, Veromann E, Winkler K, Albrecht M (2019) The potential of different semi-natural habitats to sustain pollinatiors and natural enemies in European agricultural landscapes. Agric Ecosyst Environ 279:43-52. https://doi. org/10.1016/j.agee.2019.04.009

Beyer N, Gabriel D, Kirsch F, Schulz-Kesting K, Dauber J, Westphal C (2020) Functional groups of wild bees respond differently to faba bean Vicia faba L. cultivation at landscape scale. J Appl Ecol 57:2499-2508. https://doi.org/10. 1111/1365-2664.13745

Bond DA, Poulsen MH (1983) Pollination. In: Hebblethwaite PD (ed) The Faba Bean (Vicia faba L.). Butterworths, London, pp 77-101

Brooks ME, Kristensen K, van Benthem K, Koen J, Magnusson A, Berg CW, Nielsen A, Skaug HJ, Machler M, Bolker BM (2017) glmmTMB balances speed and flexibility among packages for zero-inflated generalized linear mixed modeling. The R Journal 9:378-400. https://doi.org/10.3929/ ethz-b-000240890

Burnham KP, Anderson DR (2002) Model Selection and multimodel inference. a practical information-theoretic approach, 2nd edn. Springer

Destatis. Statistisches Bundesamt. https://www.destatis.de/DE/ Themen/Branchen-Unternehmen/LandwirtschaftForstwirtschaft-Fischerei/Flaechennutzung/_inhalt.html. Accessed 14 May 2020

Diekötter T, Kadoya T, Peter F, Wolters V, Jauker F (2010) Oilseed rape crops distort plant-pollinator interactions. J Appl Ecol 47:209-214. https://doi.org/10.1111/j.13652664.2009.01759.x

Diekötter T, Peter F, Jauker B, Wolters V, Jauker F (2014) Mass-flowering crops increase richness of cavity-nesting bees and wasps in modern agro-ecosystems. GCB Bioenergy 6:219-226. https://doi.org/10.1111/gcbb.12080

European Commission (2017) Evaluation study of the payment for agricultural practices beneficial for the climate and the environment - final report. European Commission, Brussels.

Fox J, Weisberg S (2019) An R Companion to Applied Regression, 3rd edn. Sage, Thousand Oaks CA. http:// tinyurl.com/carbook.

Gámez-Virués S, Perović DJ, Gossner MM, Börschig C, Blüthgen N, de Jong H, Simons NK, Klein AM, Krauss J, Maier G, Scherber C, Steckel J, Rothenwöhrer C, SteffanDewenter J, Weiner CN, Weisser W, Werner M, Tscharntke T, Westphal C (2015) Landscape simplification 
filters species traits and drives biotic homogenization. Nat Commun. https://doi.org/10.1038/ncomms9568

Garibaldi LA, Bartomeus I, Bommarco R, Klein AM, Cunningham SA, Aizen MA, Boreux V, Garratt MPD, Carvalheiro LG, Kremen C, Morales CL, Schüepp C, Chacoff NP, Freitas BM, Gagic V, Holzschuh A, Klatt BK, Krewenka KM, Krishnan S, Mayfield MM, Motzke I, Otieno M, Petersen J, Potts SG, Ricketts TH, Rundlöf M, Sciligo A, Sinu PA, Steffan-Dewenter I, Taki H, Tscharntke T, Vergara CH, Viana BF, Woyciechowski M (2015) Trait matching of flower visitors and crops predicts fruit set better than trait diversity. J Appl Ecol 52:1436-1444. https://doi.org/10.1111/1365-2664.12530

Garratt MPD, Coston DJ, Truslove CL, Lappage MG, Polce C, Dean R, Potts SG (2014) The identity of crop pollinators helps target conservation for improved ecosystem services. Biol Cons 169:128-135. https://doi.org/10.1016/j.biocon. 2013.11.001

Goulson D, Hanley ME, Darvill B, Ellis JS, Knight ME (2005) Causes of rarity in bumblebees. Biol Cons 122:1-8. https:// doi.org/10.1016/j.biocon.2004.06.017

Grab H, Brokaw J, Anderson E, Gedlinske L, Gibbs J, Wilson J, Loeb G, Isaacs R, Poveda K (2019) Habitat enhancements rescue bee body size from the negative effects of landscape simplification. J Appl Ecol 56:2144-2154. https://doi.org/ 10.1111/1365-2664.13456

Greenleaf SS, Williams NM, Winfree R, Kremen C (2007) Bee foraging ranges and their relationship to body size. Oecologia 153:589-596. https://doi.org/10.1007/s00442007-0752-9

Hanley ME, Franco M, Dean CE, Franklin EL, Harris HR, Haynes AG, Rapson SR, Rowse G, Thomas C, Waterhouse BR, Knight ME (2011) Increased bumblebee abundance along the margins of a mass flowering crop: evidence for pollinator spill-over. Oikos 120:1618-1624. https://doi. org/10.1111/j.1600-0706.2011.19233.x

Holzschuh A, Dainese M, González-Varo JP, Mudri-Stojnić S, Riedinger V, Rundlöf M, Scheper J, Wickens JB, Wickens VJ, Bommarco R, Kleijn D, Potts SG, Roberts SPM, Smith HG, Vilà M, Vujić A, Steffan-Dewenter I (2016) Massflowering crops dilute pollinator abundance in agricultural landscapes across Europe. Ecol Lett 19:1228-1236. https:// doi.org/10.1111/ele.12657

IPBES (2019) Summary for policymakers of the global assessment report on biodiversity and ecosystem services of the Intergovernmental Science-Policy Platform on Biodiversity and Ecosystem Services. Díaz S, Settele ES, Ngo HT (eds) IPBES Secretariat Bonn, Germany

Jauker F, Bondarenko B, Becker HC, Steffan-Dewenter I (2012) Pollination efficiency of wild bees and hoverflies provided to oilseed rape. Agric for Entomol 14:81-87. https://doi. org/10.1111/j.1461-9563.2011.00541.x

Kallioniemi E, Åström J, Rusch GM, Dahle S, Åström S, Gjershaug JO (2017) Local resources, linear elements and mass-flowering crops determine bumblebee occurrences in moderately intensified farmlands. Agric Ecosyst Environ 239:90-100. https://doi.org/10.1016/j.agee.2016.12.039

Kämper W, Werner PK, Hilpert A, Westphal C, Blüthgen N, Eltz T, Leonhardt SD (2016) How landscape, pollen intake and pollen quality affect colony growth in Bombus terrestris. Landscape Ecol 31:2245-2258. https://doi.org/ 10.1007/s10980-016-0395-5

Knight ME, Osborne JL, Sanderson RA, Hale RJ, Martin AP, Goulson D (2009) Bumblebee nest density and the scale of available forage in arable landscapes. Insect Conserv Divers 2:116-124. https://doi.org/10.1111/j.1752-4598. 2009.00049.x

Kremen C, Williams NM, Aizen MA, Gemmill-Herren B, LeBuhn G, Minckley R, Packer L, Potts SG, Roulston T, Steffan-Dewenter I, Vázquez DP, Winfree R, Adams L, Crone EE, Greenleaf SS, Keitt TH, Klein A-M, Regetz J, Ricketts TH (2007) Pollination and other ecosystem services produced by mobile organisms: a conceptual framework for the effects of land-use change. Ecol Lett 10:299-314. https://doi.org/10.1111/j.1461-0248.2007. 01018.x

Laliberté E, Legendre P (2010) A distance-based framework for measuring functional diversity from multiple traits. Ecology 91:299-305

Leidenfrost RM, Bänsch S, Prudnikow L, Brenig B, Westphal C, Wünschiers R (2020) Analyzing the dietary diary of bumble bee. Front Plant Sci 11:1-9. https://doi.org/10. 3389/fpls.2020.00287

Lenth R (2019) emmeans: Estimated Marginal Means, aka Least-Squares Means. R package version 1.4.1. https:// CRAN.R-project.org/package $=$ emmeans

Link WA, Barker RJ (2006) Model weights and the foundations of multimodel inference. Ecology 87:2626-2635. https:// doi.org/10.1890/0012-9658(2006)87[2626:MWATFO]2. $0 . \mathrm{CO} ; 2$

Mauss V (1994) Bestimmungsschlüssel für HUMMELN, 5th edn. Deutscher Jugendbund für Naturbeobachtung, Hamburg

Mandelik Y, Winfree R, Neeson T, Kremen C (2012) Complementary habitat use by wild bees in agro-natural landscapes. Ecol Appl 22:1535-1546. https://doi.org/10.1890/ 11-1299.1

Marzinzig B, Brünjes L, Biagioni S, Behling H, Link W, Westphal C (2018) Bee pollinators of faba bean (Vicia faba L.) differ in their foraging behaviour and pollination efficiency. Agric Ecosyst Environ 264:24-33. https://doi.org/ 10.1016/j.agee.2018.05.003

Nayak GK, Roberts SPM, Garratt M, Breeze TD, Tscheulin T, Harrison-Cripps J, Vogiatzakis IN, Stirpe MT, Potts SG (2015) Interactive effect of floral abundance and seminatural habitats on pollinators in field beans (Vicia faba). Agric Ecosyst Environ 199:58-66. https://doi.org/10.1016/ j.agee.2014.08.016

Oliveira MO, Freitas BM, Scheper J, Kleijn D (2016) Size and sex-dependent shrinkage of Dutch bees during one-and-ahalf centuries of land-use change. PLoS One 11:1-8. https://doi.org/10.1371/journal.pone.0148983

Perović D, Gámez-Virués S, Börschig C, Klein AM, Krauss J, Steckel J, Rothenwöhrer C, Erasmi S, Tscharntke T, Westphal C (2015) Configurational landscape heterogeneity shapes functional community composition of grassland butterflies. J Appl Ecol 52:505-513. https://doi. org/10.1111/1365-2664.12394

Persson AS, Smith HG (2011) Bumblebee colonies produce larger foragers in complex landscapes. Basic Appl Ecol 12:695-702. https://doi.org/10.1016/j.baae.2011.10.002 
Pinheiro J, Bates D, DebRoy S, Sarkar D, R Core Team (2019) nlme: linear and nonlinear mixed effects models. R package version 3.1-140. https://CRAN.R-project.org/ package $=$ nlme

Potts SG, Biesmeijer JC, Kremen C, Neumann P, Schweiger O, Kunin WE (2010) Global pollinator declines: trends, impacts and drivers. Trends Ecol Evol 25:345-353. https:// doi.org/10.1016/j.tree.2010.01.007

Potts SG, Vulliamy B, Dafni A, Ne'eman G, Willmer P (2003) Linking bees and flowers: how do floral communities structure pollinator communities? Ecology 84:2628-2642. https://doi.org/10.1890/02-0136

QGIS Development Team. (2016). QGIS geographic information system. Open Source Geospatial Foundation Project. Retrieved from http://qgis.osgeo.org

R Core Team (2019) R: a language and environment for statistical computing. Austria, R Foundation for Statistical Computing, Vienna

Radmacher S, Strohm E (2010) Factors affecting offspring body size in the solitary bee Osmia bicornis (Hymenoptera, Megachilidae). Apidologie 41:169-177. https://doi.org/10. 1051/apido/2009064

Raftery AE (1995) Bayesian model selection in social research. Sociol Methodol 25:111-163

Rundlöf M, Persson AS, Smith HG, Bommarc R (2014) Lateseason mass-flowering red clover increases bumble bee queen and male densities. Biol Cons 172:138-145. https:// doi.org/10.1016/j.biocon.2014.02.027

Schellhorn NA, Gagic V, Bommarco R (2015) Time will tell: resource continuity bolsters ecosystem services. Trends Ecol Evol 30:524-530. https://doi.org/10.1016/j.tree.2015. 06.007

Scheper J, Reemer M, van Kats R, Ozinga WA, van der Linden GTJ, Schaminée JHJ, Siepel H, Kleijn D (2014) Museum specimens reveal loss of pollen host plants as key factor driving wild bee decline in The Netherlands. PNAS 111:17552-17557. https://doi.org/10.1073/pnas. 1412973111

Shackelford G, Steward PR, Benton TG, Kunin WE, Potts SG, Biesmeijer JC, Sait SM (2013) Comparison of pollinators and natural enemies: a meta-analysis of landscape and local effects on abundance and richness in crops. Biol Rev 88:1002-1021. https://doi.org/10.1111/brv.12040

Somme L, Vanderplanck M, Michez D, Lombaerde I, Moerman R, Wathelet B, Wattiez R, Lognay G, Jacquemart AL (2015) Pollen and nectar quality drive the major and minor floral choices of bumble bees. Apidologie 46:92-106. https://doi.org/10.1007/s13592-014-0307-0

Steffan-Dewenter I, Münzenberg U, Bürger C, Thies C, Tscharntke T (2002) Scale-dependent effects of landscape context on three pollinator guilds. Ecology 83:1421-1432. https://doi.org/10.1890/0012-9658(2002)083[1421: SDEOLC]2.0.CO;2

Steckel J, Westphal C, Peters MK, Bellach M, Rothenwoehrer C, Erasmi S, Scherber C, Tscharntke T, Steffan-Dewenter I (2014) Landscape composition and configuration differently affect trap-nesting bees, wasps and their antagonists. Biol Cons 172:56-64

Sutter L, Jeanneret P, Bartual AM, Bocci G, Albrecht M (2017) Enhancing plant diversity in agricultural landscapes promotes both rare bees and dominant crop-pollinating bees through complementary increase in key floral resources. J Appl Ecol 54:1856-1864. https://doi.org/10.1111/13652664.12907

Timberlake TP, Vaughan IP, Memmott J (2019) Phenology of farmland floral resources reveals seasonal gaps in nectar availability for bumblebees. J Appl Ecol 56:1585-1596. https://doi.org/10.1111/1365-2664.13403

Vanbergen AJ, Initiative TIP (2013) Threats to an ecosystem service: pressures on pollinators. Front Ecol Environ 11:251-259

Wagenmakers EJ, Farrell S (2004) AIC model selection using Akaike weights. Psychon Bull Rev 11:192-196. https://doi. org/10.3758/BF03206482

Walther-Hellwig K, Frankl R (2000) Foraging habitats and foraging distances of bumblebees, Bombus spp. (Hym., Apidae), in an agricultural landscape. J Appl Entomol 124:299-306. https://doi.org/10.1046/j.1439-0418.2000. 00484.x

Westphal C, Bommarco R, Carré G, Lamborn E, Morison N, Petanidou T, Potts SG, Roberts SPM, Szentgyörgyi H, Tscheulin T, Vaissière BE, Woyciechowski M, Biesmeijer JC, Kunin WE, Settele J, Steffan-Dewenter I (2008) Measuring bee diversity in different European habitats and biogeographical regions. Ecol Monogr 78:653-671. https://doi.org/10.1890/07-1292.1

Westphal C, Steffan-Dewenter I, Tscharntke T (2003) Mass flowering crops enhance pollinator densities at a landscape scale. Ecol Lett 6:961-965. https://doi.org/10.1046/j.14610248.2003.00523.x

Westphal C, Steffan-Dewenter I, Tscharntke T (2009) Mass flowering oilseed rape improves early colony growth but not sexual reproduction of bumblebees. J Appl Ecol 46:187-193. https://doi.org/10.1111/j.1365-2664.2008. 01580.x

Westrich P (2018) Die Wildbienen Deutschlands, 1st edn. Eugen Ulmer Verlag, Stuttgart

Westrich P, Frommer U, Mandery K, Riemann H, Ruhnke H, Saure C, Voith J (2011) Rote Liste und Gesamtartenliste der Bienen (Hymenoptera, Apidae) Deutschlands. Naturschutz Und Biologische Vielfalt 70:373-416

Wickham H (2016) ggplot2: Elegant Graphics for Data Analysis. Springer-Verlag New York. https://ggplot2.tidyverse. org.

Woodcock BA, Edwards M, Redhead J, Meek WR, Nuttall P, Falk S, Nowakowski M, Pywell RF (2013) Crop flower visitation by honeybees, bumblebees and solitary bees: behavioural differences and diversity responses to landscape. Agric Ecosyst Environ 171:1-8. https://doi.org/10. 1016/j.agee.2013.03.005

Woodcock BA, Garratt MPD, Powney GD, Shaw RF, Osborne JL, Soroka J, Lindström SA, Stanley D, Ouvrard P, Edwards ME, Jauker F (2019) Meta-analysis reveals that pollinator functional diversity and abundance enhance crop pollination and yield. Nat Commun 10:1-10. https://doi. org/10.1038/s41467-019-09393-6

Publisher's Note Springer Nature remains neutral with regard to jurisdictional claims in published maps and institutional affiliations. 